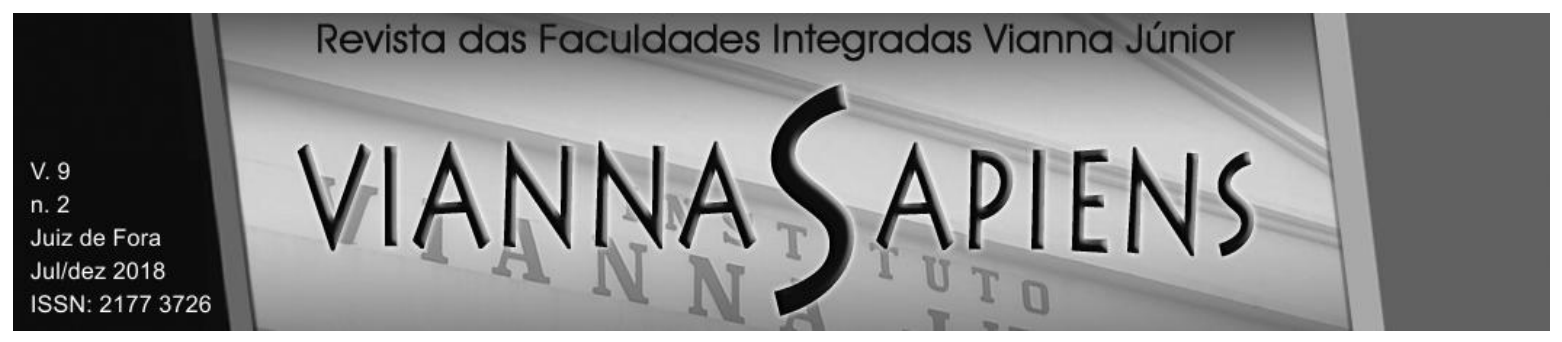

\title{
A RELATIVIZAÇÃo DA COISA JULGADA NO DIREITO DE FAMÍLIA NO ÂMBITO DO SUPREMO TRIBUNAL FEDERAL
}

DOI: 10.31994/rvs.v9i2.339

Laís Botelho Oliveira Álvares ${ }^{1}$

\section{RESUMO}

O presente artigo tem como objetivo analisar a possibilidade da relativização da coisa julgada material nas ações de investigação de paternidade onde não houve a realização do exame de DNA, uma vez que esta prova pericial é fundamental para a designação inequívoca da paternidade. Assim sendo, partimos da análise do RE $n^{\circ}$ 363.889, no qual o Supremo Tribunal Federal abordou esta questão a fim de possibilitar que o suposto descendente ingresse novamente com demanda em face de seu suposto genitor, para descobrir sua verdadeira identidade biológica. Trata-se de um hard case onde a solução só poderá ser encontrada através do método de ponderação de valores como o da segurança jurídica e o da dignidade humana. Por meio de revisão bibliográfica e minuciosa análise dos votos dos Ministros, ensaiamos este trabalho, corroborando o louvável entendimento da Corte, que teve por bem constatar que o direito personalíssimo ao reconhecimento paterno é imprescritível e decorrente da dignidade humana, realidade capaz de afastar a norma processual, que se revelou in casu, como um obstáculo superável.

\footnotetext{
${ }^{1}$ Bacharela em Direito nas Faculdades Integradas Vianna Júnior. Pós-graduada em Processo pela Universidade Federal de Juiz de Fora, em Direito Civil pela Universidade Gama Filho e em Direito Público pela universidade Cândido Mendes. Acadêmica do curso de Filosofia na Universidade Federal de Juiz de Fora. Advogada. : https://orcid.org/0000-0002-8144-6164
} 


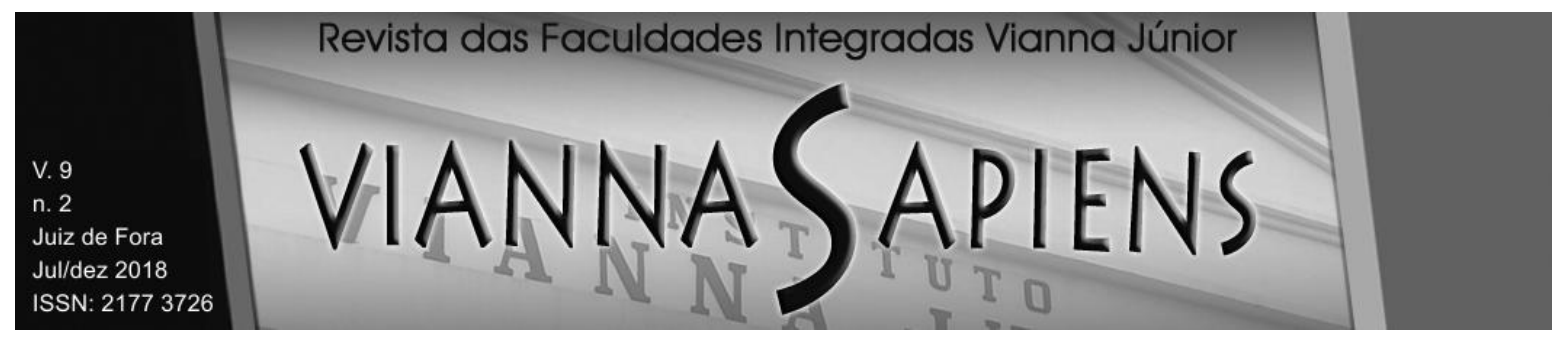

\title{
PALAVRAS-CHAVE: COISA JULGADA. SEGURANÇA JURÍDICA. RELATIVIZAÇÃO. INVESTIGAÇÃO DE PATERNIDADE.
}

\section{THE RELAXATION OF THE THING JUDGED IN FAMILY LAW IN THE FRAMEWORK OF THE SUPREME FEDERAL COURT}

\begin{abstract}
The objective of this article is to analyze the possibility of relativization of the material thing considered in the actions of paternity investigation where the DNA test was not performed, since this expert evidence is fundamental for the unequivocal designation of paternity. Thus, we started with the analysis of RE No. 363,889, in which the Federal Supreme Court addressed this issue in order to enable the alleged descendant to re-register with his alleged parent in order to discover his true biological identity. It is a hard case where the solution can only be found through the method of weighing values such as legal certainty and human dignity. Through a bibliographical review and a detailed analysis of the votes of the Ministers, we rehearse this work, corroborating the praiseworthy understanding of the Court, which had to confirm that the very personal right to paternal recognition is imprescriptible and derives from human dignity, a reality capable of removing the norm procedural law, which has proved to be an transposable obstacle.
\end{abstract}

KEYWORDS: RES JUDICATA. LEGAL SECURITY. RELATIVIZATION. INVESTIGATION OF PATERNITY. 


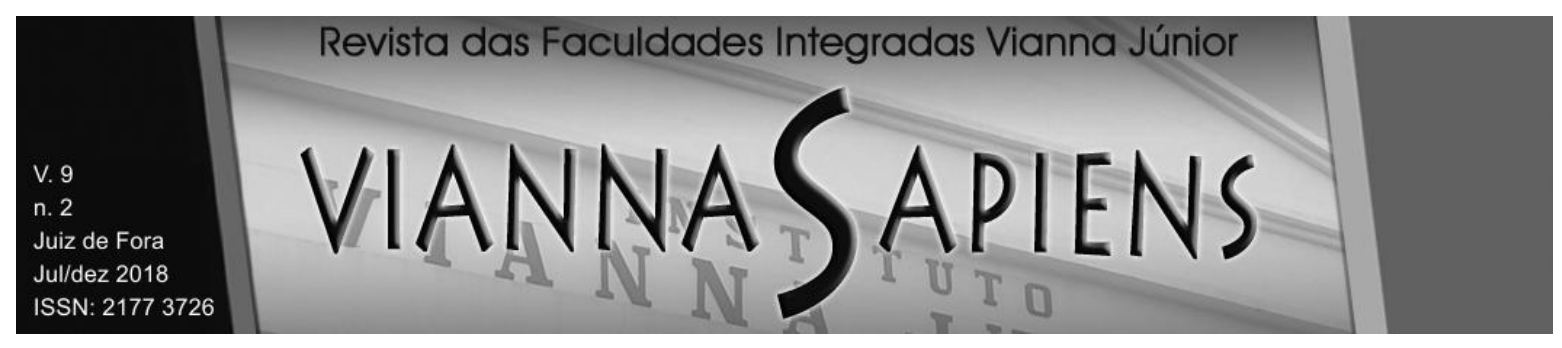

\section{INTRODUÇÃO}

Nos últimos tempos, tem sido discutido na doutrina e jurisprudência, a respeito da possibilidade de se relativizar a supremacia da coisa julgada em ações de investigação de paternidade, nos casos em que o prazo decadencial para ingressar com ação rescisória já caducou e o objeto da coisa julgada se mostrar posteriormente incompatível com os direitos fundamentais, afrontando diretamente a dignidade da pessoa humana. O debate ganhou maior repercussão após o Supremo Tribunal Federal ter decidido no Recurso Extraordinário $n^{\circ} 363.889$, pela desconsideração da coisa julgada no caso de investigação de paternidade cuja sentença que havia negado a paternidade por ausência de provas e que transitou em julgado há mais de dois anos pudesse ser desconsiderada, independentemente de ajuizamento de ação rescisória, para que houvesse nova demanda com o mesmo pedido, pelo fato de que, na época em que foi ajuizada a primeira ação de investigação, o autor que estava sob assistência judiciária gratuita, não tinha condições de custear o exame de DNA, prova fundamental para a decisão judicial.

Especificamente nesse caso, encontra-se um embate entre a garantia fundamental da coisa julgada material, prevista no art. $5 .^{\circ}, \mathrm{XXXVI}$ da Constituição Federal, corolário do princípio da segurança jurídica, que está previsto no art. 5. caput da Constituição em contraposição ao direito fundamental à filiação e à garantia fundamental da assistência judiciária gratuita, previstos nos artigos 227 , caput e $\S 6^{\circ}$ e $5^{\circ}$, LXXIV, respectivamente, bem como o princípio da dignidade da pessoa humana, previsto no art. $1 .^{\circ}, \mathrm{III}, \mathrm{CF}$. Sendo assim, o presente ensaio visa discutir os pontos mais importantes da decisão do Recurso Extraordinário $n^{\circ} 363.889$, bem como analisar os fundamentos constitucionais que baseiam a excepcionalidade que autoriza o afastamento da coisa julgada em benefício dos direitos fundamentais à filiação e à assistência judiciária gratuita. 


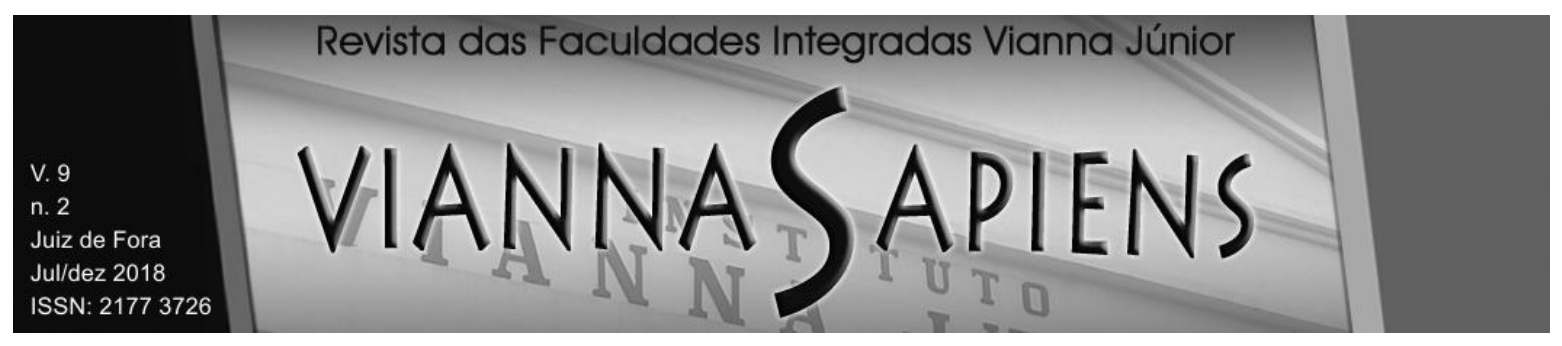

\section{A COISA JULGADA E A SUA RELATIVIZAÇÃO}

Coisa julgada pode ser compreendida como a imutabilidade de decisão, por não ser mais cabível nenhuma revisão ou recurso (Art. 502, novo Código de Processo Civil). O instituto da coisa julgada encontra fundamento nos princípios da segurança jurídica e do estado democrático de direito, alpem disso, está previsto no art. $5^{\circ}, \mathrm{XXXVI}$ da Constituição Federal, que dispõe que "a lei não prejudicará o direito adquirido, o ato jurídico perfeito e a coisa julgada". Como bem ensina Humberto Theodoro Jr., um dos efeito que a sentença pode produzir é a formação da coisa julgada. Esta estará presente com o trânsito em julgado da sentença, quando ela receberá as características de definitividade e imutabilidade. Oportunidade na qual a sentença deixa de ser um simples ato jurisdicional e passa a ser reconhecida pela ordem jurídica como a emanação da vontade da lei (2008).

Nessa vereda, podemos entender que a coisa julgada é um instituro de natureza processual que visa proteger a segurança jurídica, na medida em que, após o trânsito em julgado da sentença, a torna imutável.

De acordo com Leonardo Greco( 2007) a coisa julgada deve ser entendida como uma espécie de garantia da segurança jurídica e da tutela jurisdicional. A partir do momento em que a existência de um direito foi reconhecida, através de decisão não mais sujeita a qualquer recurso no processo em que foi proferida, o Estado deve assegurar a sua plena imutabilidade. Dessa forma, a coisa julgada significa uma garantia essencial do direito fundamental à segurança jurídica, sendo esta considerada "o mínimo de previsibilidade necessária que o Estado de Direito deve oferecer a todo cidadão, a respeito de quais são as normas de convivência que ele deve observar e com base nas quais pode travar relações jurídicas válidas e eficazes" Humberto Theodoro Junior ( 2008) ao relembrar as lições de Liebman, conclui que o fundamento que justifica a coisa julgada reside no fato de que a sociedade necessita dos efeitos da imutabilidade, uma vez que evita a perpetuação de litígios e traz segurança nas relações jurídicas. Leonardo Greco ( 2007), embora dê primazia para a imutabilidade da coisa julgada e preze pela sua manutenção, 


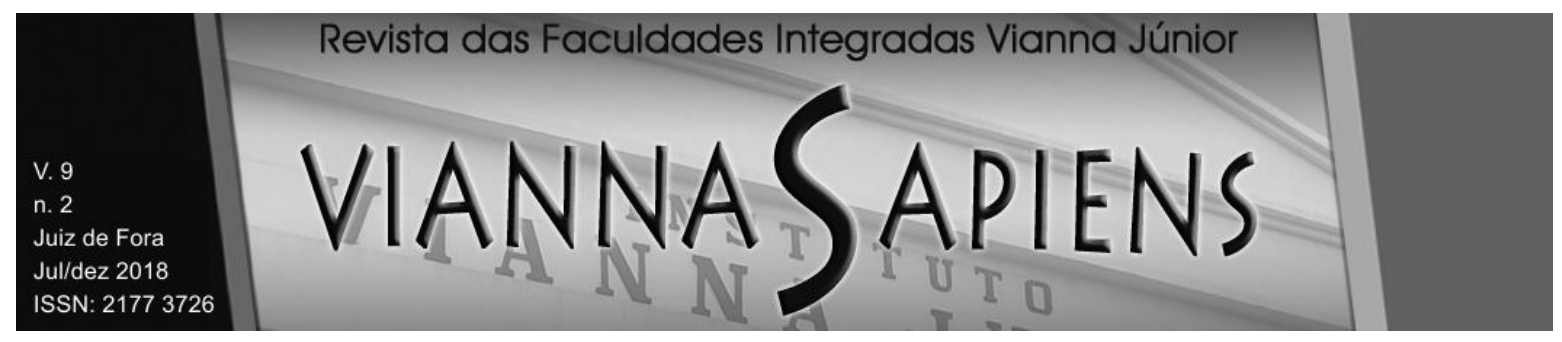

admite que possa haver seu afastamento em situações específicas, tendo em vista a técnica da ponderação de valores, haja vista que a segurança jurídica não é um direito absoluto, como absoluto não é nenhum outro direito fundamental .

Luiz Guilherme Marinoni ( 2007, p. 18) ao dissertar sobre a possibilidade da relativização da coisa julgada diz:

Em valor da "relativização" da coisa julgada, argumenta-se a partir de três princípios: o da proporcionalidade, o da legalidade e o da instrumentalidade. No exame desse último, sublinha-se que o processo, quando visto em sua dimensão instrumental, somente tem sentido quando o julgamento estiver pautado pelos ideais de Justiça e adequado à realidade. Em relação ao princípio da legalidade, afirma-se que, como o poder do estado deve ser exercido nos limites da lei, não é possível pretender conferir a proteção da coisa julgada a uma sentença totalmente alheia ao direito positivo. Por fim, no que diz respeito ao princípio da proporcionalidade, sustenta-se que a coisa julgada, por ser apenas um dos valores protegidos constitucionalmente, não pode prevalecer sobre outros valores que têm o mesmo grau hierárquico. Admitindo-se que a coisa julgada pode se chocar com outros princípios igualmente dignos de proteção, conclui-se que a coisa julgada pode ceder diante de outro valor merecedor de agasalho.

Sendo assim, podemos concluir que havendo embate entre valores constitucionalmente protegidos, como é o caso do princípio da segurança jurídica versus o direito do filho em descobrir sua verdade biológica, independentemente de já ter havido a coisa julgada, só poderá ser solucionado através do método de ponderação.

\subsection{A AÇÃO RESCISÓRIA COMO INSTRUMENTO HÁBIL PARA A DESCONSIDERAÇÃO DA COISA JULGADA}

A ação rescisória, prevista no art. 966 e seguintes do novo Código Processual Civil, é o meio previsto em lei para possibilitar, em rol taxativo, os casos em que possa haver a relativização da coisa julgada. A respeito das possibilidades do cabimento de ação rescisória, mais especificamente o inciso VII, art. 966 do CPC, 


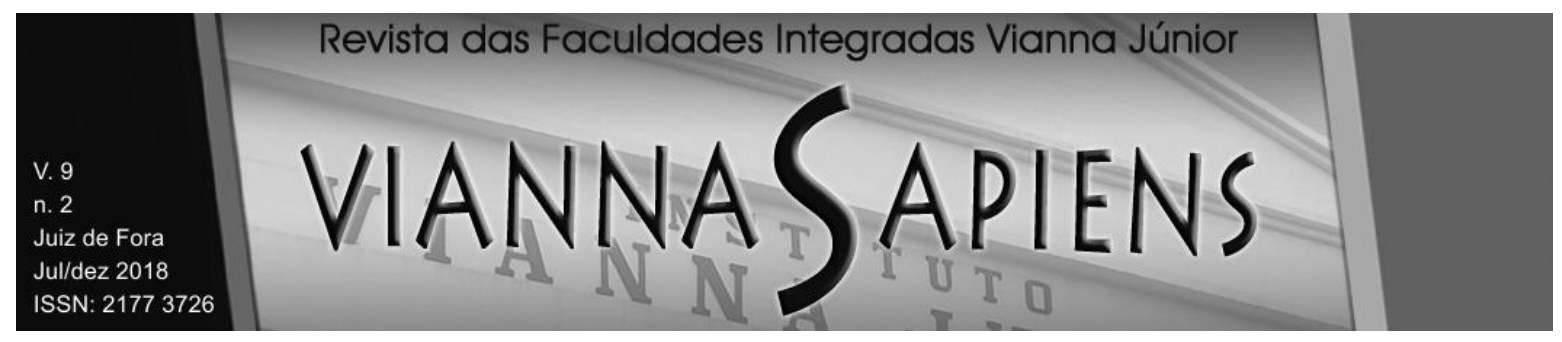

permite-se a utilização desse instrumento nos casos de documento novo de existência ignorada ou de que não pôde ser usado. A simples leitura desse dispositivo nos leva a aceitar a utilização da ação rescisória nos casos de investigação de paternidade onde não houve exame de DNA. Apesar disso, Luiz Guilherme Marinoni ( 2007), defende que o exame de DNA não tem o caráter de documento novo, é todavia, uma técnica pericial que ainda não existia na época da ação. Sustenta também que o documento novo a que se refere o art. 966, deveria existir no momento do ajuizamento da demanda e que, por motivos alheios à vontade da parte, não pôde ser juntado aos autos.

Não obstante o respeitável posicionamento do autor, a jurisprudência do Superior Tribunal de Justiça já pacificou o entendimento de que o exame de DNA pode sim ser considerado documento novo a que se refere 0 artigo supramencionado, para fins de ajuizamento de ação rescisória, como podemos extrair dos seguintes acórdãos:

CIVIL. PROCESSO CIVIL. RECURSO ESPECIAL. AÇÃO RESCISÓRIA. INVESTIGAÇÃO DE PATERNIDADE. EXAME DE DNA. DOCUMENTO NOVO. 1. Como documento novo, deve-se entender aquele que já existia quando da prolação da sentença, mas cuja existência era ignorada pelo autor da rescisória, ou que dele não pode fazer uso. Hipótese dos autos. 2. Deve ser de tal ordem que, sozinho, seja capaz de modificar o resultado da decisão rescindenda, favorecendo o autor da rescisória. 3. Esta Corte Superior já sedimentou o entendimento de que "O laudo do exame de DNA, mesmo realizado após a confirmação pelo juízo ad quem da sentença que julgou procedente a ação de investigação de paternidade, é considerado documento novo para o fim de ensejar a ação rescisória (art. 485, VII, CPC). Precedente citado: REsp. 189.306 MG, DJ 25/8/2003." (REsp 300.084-GO, Rel. Min. Humberto Gomes de Barros, 2a Seção, julgado em 28/4/2004). 4. Recurso Especial provido. (STJ, REsp. $n^{\circ}$ 653.942, 4. ${ }^{\mathrm{a}}$ Turma, j. 15.09.2009, rel. Min. Honildo Amaral de Mello Castro.)

AÇÃO RESCISÓRIA - INVESTIGAĈ̃O DE PATERNIDADE EXAME DE DNA APÓS O TRÂNSITO EM JULGADO POSSIBILIDADE -FLEXIBILIZAÇÃO DO CONCEITO DE DOCUMENTO NOVO NESSES CASOS. SOLUÇÃO PRÓ VERDADEIRO "STATUS PATER". O laudo do exame de DNA, mesmo posterior ao exercício da ação de investigação de 


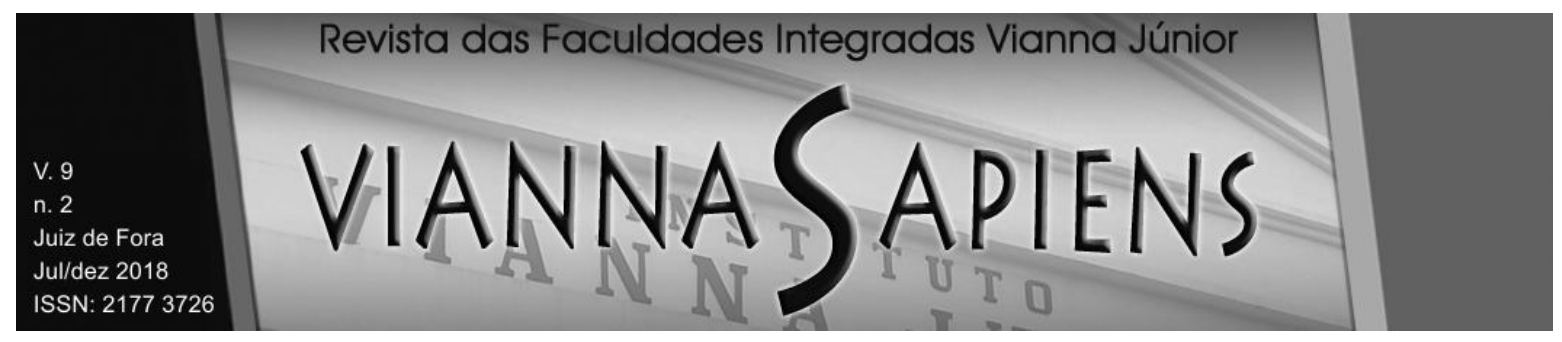

paternidade, considera-se "documento novo" para aparelhar ação rescisória (CPC, art. 485, VII). É que tal exame revela prova já existente, mas desconhecida até então. A prova do parentesco existe no interior da célula. Sua obtenção é que apenas se tornou possível quando a evolução científica concebeu o exame intracitológico. (STJ, REsp n 300.084, 2. a Seção, j. 28.04.2004, rel. Min. Humberto Gomes de Barros.)

Assim sendo, o instrumento hábil para a relativização da coisa julgada na investigação de paternidade é a ação rescisória.

No entanto, tendo em vista que o referido exame apenas chegou ao Brasil em meados dos anos oitenta, houveram inúmeras ações de investigação de paternidade que foram julgadas improcedentes por falta de provas e que atualmente não podem ser objeto de ação rescisória tendo em face o prazo decadencial de dois anos para a sua propositura (MEIRELES, 2011). Destarte, o Ministro Luiz Fux, em seu voto, no RE 363.889/DF, sugeriu que fosse realizada uma nova contagem do prazo decadencial para a ação rescisória nesses casos:

Em outras palavras, a harmonização entre os princípios constitucionais da segurança jurídica, de um lado, e do direito fundamental à filiação e da garantia da assistência jurídica aos desamparados, de outro, consiste na aplicação analógica do marco inicial flexibilizado para o ajuizamento da ação rescisória, que não pode permanecer rigidamente contado da data do trânsito em julgado. Ao contrário, o marco para a contagem dos dois anos deve poder ser alterado quando demonstrado pelo autor, argumentativamente, que não pudera ajuizar, anteriormente, a demanda, pela impossibilidade prática de obtenção do exame de DNA. Desta forma, é apenas da data da possibilidade prática de obtenção do DNA que deve ser contado o referido prazo, pois apenas nesse momento que se mostra possível o exercício, in concreto, do direito à tutela jurisdicional efetiva, de modo que, apenas nessas condições, a omissão em fazê-lo poderá ser imputada à própria parte. Nessa linha, e em razão da abertura deste parâmetro para a definição do marco inicial para o prazo de dois anos, deve ser entendido como ônus do autor da demanda a demonstração de que somente Ihe foi assegurada a possibilidade prática de obtenção da nova prova no espaço inferior a dois anos contados da data da propositura. Caso não satisfeito tal ônus, o transcurso do prazo de dois anos, contados, como tradicionalmente, do trânsito em julgado da decisão anterior, formará a cognominada coisa soberanamente julgada, inalterável por qualquer demanda 


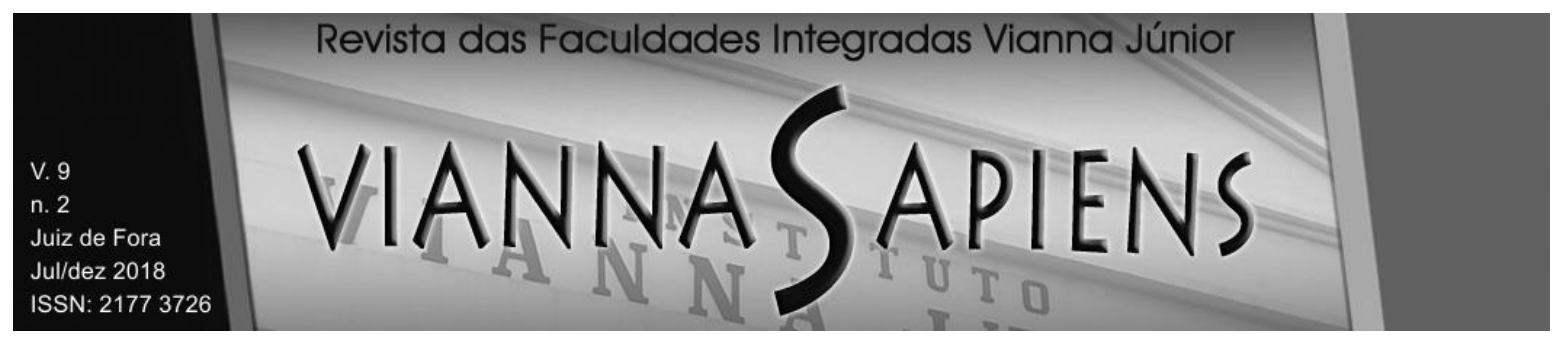

posterior (STF. RE $n^{\circ}$ 363.889. Pleno. Rel. Min. Dias Toffoli. Publicado no DJ em 16/12/2011. Disponível em: <http://www.stj.jus.br>. Acesso em 30 abr. 2018).

Partindo-se dessa premissa, torna-se necessário partir para uma análise mais profunda da possibilidade da relativização da coisa julgada nesses processos onde não foi possível a realização do exame de DNA e que, pelo lapso temporal, também não foi possível o ajuizamento de ação rescisória.

\subsection{O EXAME DE DNA COMO PROVA INCONTESTÁVEL DA RELAÇÃO DE FILIAÇÃO}

Cintra, Grinover e Dinamarco (1998, p. 347) ao dissertarem sobre a importância da prova para o processo, dizem que:

As afirmações de fatos feitas pelo autor podem corresponder ou não à verdade. $E$ a elas ordinariamente se contrapõem as afirmações de fato feitas pelo réu em sentido oposto, as quais, por sua vez, também podem ser ou não ser verdadeiras. As dúvidas sobre a veracidade das afirmações de fato feitas pelo autor ou por ambas as partes no processo, a propósito de dada pretensão deduzida em juízo, constituem questões de fato que devem ser resolvidas pelo juiz, à vista da prova dos fatos pretéritos relevantes. A prova constitui, pois, o instrumento por meio do qual se forma a convicção do juiz a respeito da ocorrência ou inocorrência dos fatos controvertidos no processo.

Ocorre que, em relação às demandas de investigação de paternidade, a prova pericial do exame de DNA, em determinados casos, é importantíssima para a comprovação da verdade dos fatos e, por conseguinte, para a formação da convicção do juiz. Ocorria anteriormente, porém, na época em que o referido exame ainda não tinha sido descoberto ou na época em que o Estado não custeava o exame, que inúmeras ações nesse sentido foram julgadas improcedentes por falta de provas, nas situações onde o autor não tinha chance de produzir outros meios de 


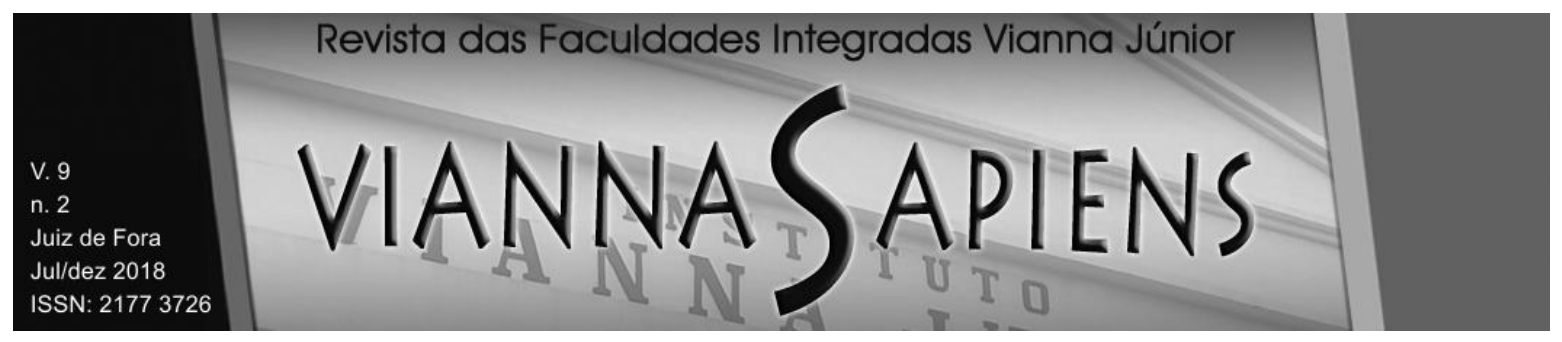

prova da filiação biológica ${ }^{2}$. Ainda que o direito processual civil conceda ao juiz a liberdade e independência para a valoração das provas, incluindo prova testemunhal e documental, não pode o magistrado, atualmente, abrir mão do exame de DNA, prova praticamente incontestável da filiação biológica, para decidir a demanda evidentemente no que concerne à filiação biológica pois no que tange a filiação socioafetiva, este raciocínio é aplicado através de princípios diversos.

A utilização de provas indiretas só se justificava na época em que não havia tal exame. Por isso, uma grande parte da doutrina defende que, demandas relativas à investigação de paternidade onde não foi utilizado o exame de DNA como prova pericial, podem ser reabertas para que se descubra a verdade real dos fatos, através da realização do exame de DNA (MEIRELES, 2011). Ainda em relação aos meios probatórios, Alexandre Freitas Câmara (2003), ao discorrer sobre a verdade real e a verdade formal, afirma que o processo civil busca a verdade real, ou seja, seu objetivo é atingir um grau de certeza que dê total respaldo para a decisão jurisdicional. E nos casos onde seja praticamente impossível de se encontrar a certeza, só resta ao magistrado buscar a verdade formal, sentenciando o juiz com base nas probabilidades, em nome da segurança jurídica. Em relação ao exame de DNA, vemos que é uma prova que garante, a priori, um grau absoluto de certeza. Podemos perceber, dessa forma, que a evolução dos meios científicos possui grande importância para a descoberta da relação de filiação. Atualmente, o exame de DNA consegue informar com exatidão o vínculo biológico existente entre o investigando e o investigado. Por isso, há atualmente no Brasil correntes doutrinárias que acertadamente defendem a quebra da coisa julgada nas demandas que não contaram com o exame de DNA, a fim de conceder aos jurisdicionados sentenças baseadas em provas infalíveis.

\footnotetext{
${ }^{2}$ Existem outros meios de prova que podem ser usados em demandas de investigação de paternidade. Em relação à prova pericial do exame de DNA, pode-se dizer que até o presente momento é a prova mais determinante de paternidade biológica.
} 


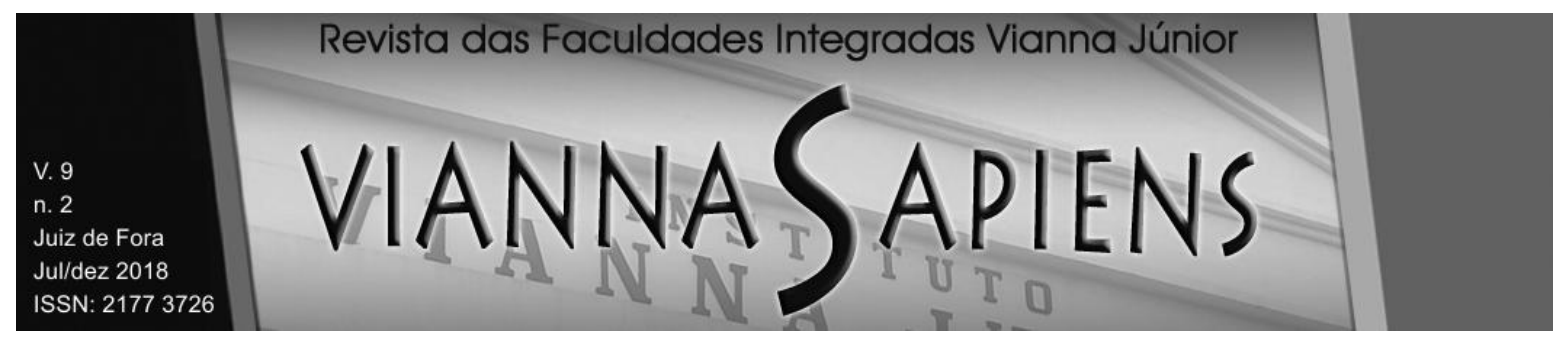

\section{O JULGADO PARADIGMA DO SUPREMO TRIBUNAL FEDERAL}

O julgado paradigma, realizado em 02 de junho de 2011, permitiu que um rapaz pleiteasse a investigação de paternidade pela segunda vez em relação ao mesmo suposto pai, sendo que o processo inicial foi julgado improcedente por falta de provas em primeira instância. O primeiro processo foi proposto em 1989 e julgado improcedente por falta de provas. Esse fato ocorreu uma vez que na época, a mãe do então menor não tinha condições financeiras para arcar com o exame de DNA. Além disso, embora estivesse sob os auspícios da assistência judiciária gratuita, ainda não havia lei que permitisse que tal prova fosse custeada pelo Poder Público. Nessa toada, após a edição de lei que garantisse o custeio do exame de DNA pelo Estado, foi proposta nova demanda, porém, esta foi julgada extinta já no Tribunal de Justiça, devido a existência de coisa julgada. A partir de tal decisão, a parte Autora recorreu até o Supremo Tribunal Federal que decidiu a seu favor, ordenando que os autos voltassem para a primeira instância, para serem julgados novamente, desconsiderando, desta forma, os efeitos da coisa julgada, como segue abaixo:

RECURSO EXTRAORDINÁRIO. DIREITO PROCESSUAL CIVIL E CONSTITUCIONAL. REPERCUSSÃO GERAL RECONHECIDA. AÇÃO DE INVESTIGAÇÃO DE PATERNIDADE DECLARADA EXTINTA, COM FUNDAMENTO EM COISA JULGADA, EM RAZÃO DA EXISTÊNCIA DE ANTERIOR DEMANDA EM QUE NÃO FOI POSSÍVEL A REALIZAÇÃO DE EXAME DE DNA, POR SER O AUTOR BENEFICÁRIO DA JUSTIÇA GRATUITA E POR NÃO TER O ESTADO PROVIDENCIADO A SUA REALIZAÇÃO. REPROPOSITURA DA AÇÃO. POSSIBILIDADE, EM RESPEITO À PREVALÊNCIA DO DIREITO FUNDAMENTAL À BUSCA DA IDENTIDADE GENÉTICA DO SER, COMO EMANAÇÃO DE SEU DIREITO DE PERSONALIDADE.1. É dotada de repercussão geral a matéria atinente à possibilidade da repropositura de ação de investigação de paternidade, quando anterior demanda idêntica, entre as mesmas partes, foi julgada improcedente, por falta de provas, em razão da parte interessada não dispor de condições econômicas para realizar o exame de DNA e o Estado não ter custeado a produção dessa prova. 2. Deve ser relativizada a coisa julgada estabelecida em ações de investigação de paternidade em que não foi possível determinar-se a efetiva existência de vínculo 


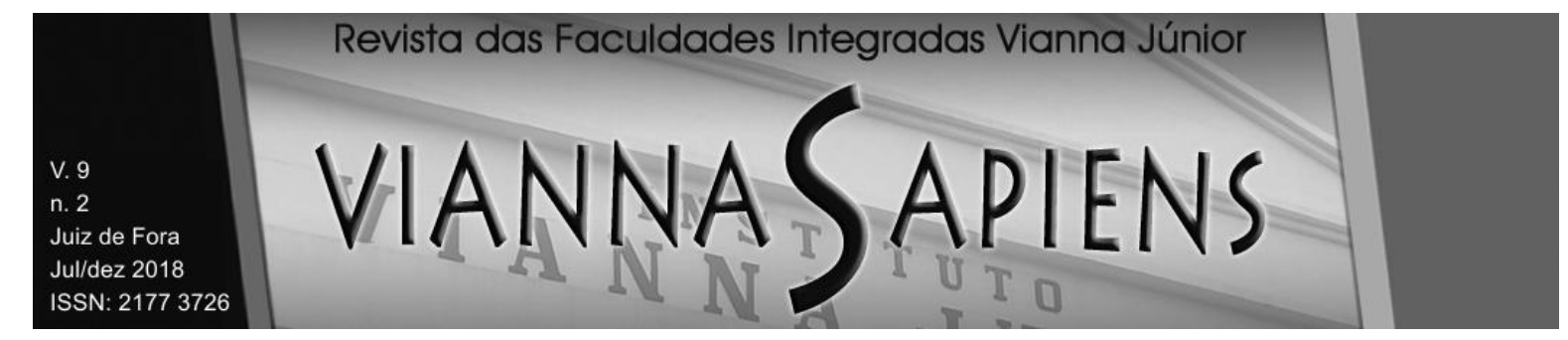

genético a unir as partes, em decorrência da não realização do exame de DNA, meio de prova que pode fornecer segurança quase absoluta quanto à existência de tal vínculo. 3. Não devem ser impostos óbices de natureza processual ao exercício do direito fundamental à busca da identidade genética, como natural emanação do direito de personalidade de um ser, de forma a tornar-se igualmente efetivo o direito à igualdade entre os filhos, inclusive de qualificações, bem assim o princípio da paternidade responsável. 4. Hipótese em que não há disputa de paternidade de cunho biológico, em confronto com outra, de cunho afetivo. Busca-se o reconhecimento de paternidade com relação a pessoa identificada. 5 . Recursos extraordinários conhecidos e providos (STF. RE $n^{\circ}$ 363.889. Pleno. Rel. Min. Dias Toffoli. Publicado no DJ em 16/12/2011. Disponível em: <http://www.stj.jus.br>. Acesso em 30 abr. 2018).

No voto do Ministro Dias Toffoli, não houve alusão ao princípio da dignidade da pessoa humana. O Ministro alertou os perigos do uso indiscriminado de tal princípio por membros do Poder Judiciário, utilizando de outros meios para a motivação de sua decisão. Ao contrário, porém, foi o parecer do Procurador-Geral da República, que opinou no sentido de que o princípio da segurança jurídica não pode obstaculizar o exercício da dignidade da pessoa humana.

Seguindo esta mesma linha de raciocínio, a maioria dos ministros do STF decidiram a favor do suposto filho, com base no princípio da dignidade da pessoa humana. O principal argumento observado pelo Ministro Relator foi o do princípio da paternidade responsável, que foi por ele ponderado em face ao princípio da segurança jurídica. Dias Toffoli lembrou o caminho histórico percorrido até chegarmos na plena igualdade entre os filhos. Nessa vereda, ele nos lembra do art. 226, $\S 7^{\circ}$ da Constituição Federal, que trata sobre a paternidade responsável e do importantíssimo art. 27 do Estatuto da Criança e do Adolescente, que diz, entre outras coisas, que o direito a descoberta de sua origem biológica é um direito imprescritível e personalíssimo, ou seja, integra a personalidade dos indivíduos. Além disso, chama a atenção para o fato de que o ECA atribui apenas a eficácia formal para a sentença que nega a paternidade. Dessa forma, lembra também, ao 


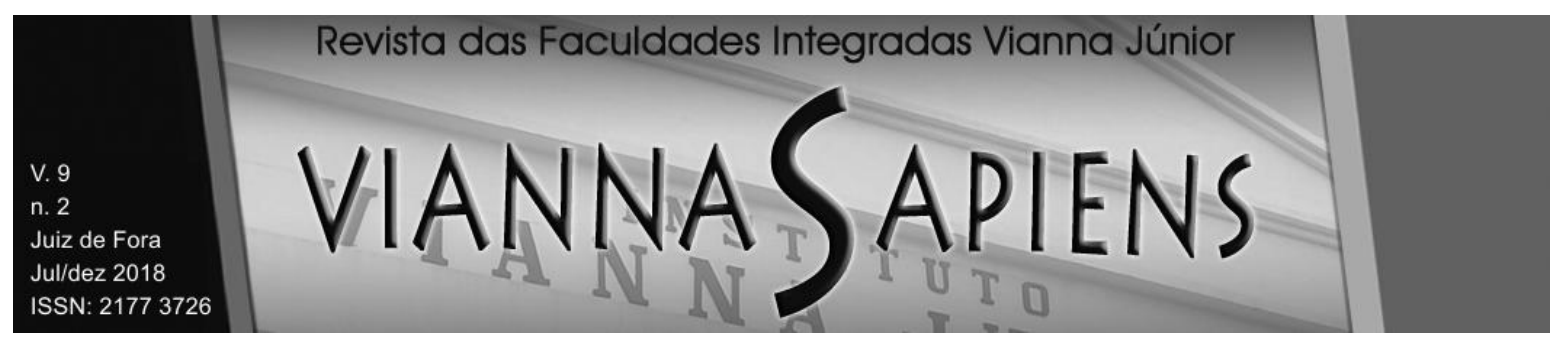

citar o verbete da Súmula $n^{\circ} 149$ do STF, que não se confundem a busca por direitos existenciais, com a busca por direitos patrimoniais.

O Relator lança mão também de outro argumento. Para ele, o exame de DNA é prova imprescindível de comprovação da filiação, já decidindo o STF anteriormente no sentido de que cabe ao Estado o custeio do exame, uma vez que ele é fundamental para a comprovação da origem biológica do indivíduo e que a descoberta de sua origem biológica é um direito fundamental dos cidadãos brasileiros, dando ênfase a importância social dessa garantia. Além disso, afirma que o exame de DNA é uma prova que se aproxima o máximo possível da verdade real. Por fim, o Ministro argumenta que, por se tratar de uma situação extremamente delicada e tão importante para a sociedade, julgar com base apenas na coisa julgada, não basta, a fundamentação judicial não pode ser deficiente.

Vale ressaltar os apontamentos feitos pelo eminente Ministro Luiz Fux, a respeito da ressalva que fez ao voto do Min. Dias Toffoli no sentido de que houve sentença de mérito no primeiro processo, de modo que está presente a coisa julgada material, nos termos dos arts. 467 e 468 do então vigente Código de Processo Civil de 1973. O Ministro Luiz Fux lembra também que a coisa julgada secundum eventum probationis apenas ocorre nos casos previstos em lei, como é o caso da ação popular e da ação civil pública. Partindo-se desta premissa, o Ministro passa a fundamentar através de outros argumentos e acaba por seguir o Relator, afastando a incidência da coisa julgada material em prol do direito fundamental a verdade biológica do indivíduo, uma vez que o status de filho possui muito mais um caráter existencial do que patrimonial. Nesse momento, o Ministro faz alusão ao princípio da dignidade da pessoa humana, uma vez que o direito ao nome e o de saber a origem biológica são atributos da personalidade.

Além disso, ao analisar sobre a produção da prova de DNA, que alega ser imprescindível para a demanda, afirma que, por se tratar de beneficiário da justiça gratuita, o filho jamais poderia ter, à luz da nossa Constituição Federal, a sorte de seus direitos pré-definida em função da carência e da hipossuficiência financeira em 


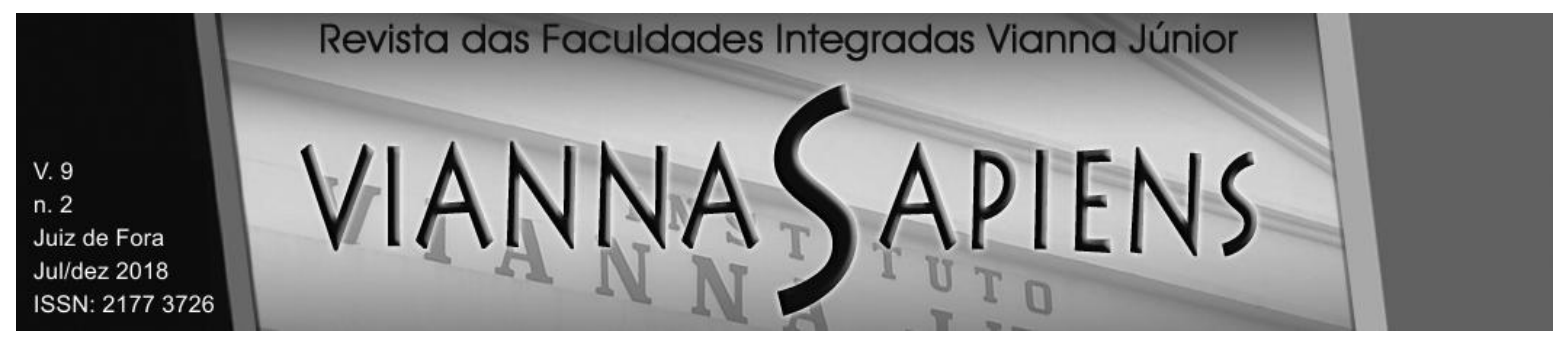

que se encontra. Antes da polêmica chegar ao STF, o Superior Tribunal de Justiça já havia decidido nesse sentido em algumas ocasiões:

PROCESSO CIVIL. INVESTIGAÇÃO DE PATERNIDADE. REPETIÇÃO DE AÇÃO ANTERIORMENTE AJUIZADA, QUE TEVE SEU PEDIDO JULGADO IMPROCEDENTE POR FALTA DE PROVAS. COISA JULGADA. MITIGAÇÃO. DOUTRINA. PRECEDENTES. DIREITO DE FAMÍLIA. EVOLUÇÃO. RECURSO ACOLHIDO.

Não excluída expressamente a paternidade do investigado na primitiva ação de investigação de paternidade, diante da precariedade da prova e da ausência de indícios suficientes a caracterizar tanto a paternidade como a sua negativa, e considerando que, quando do ajuizamento da primeira ação, o exame pelo DNA ainda não era disponível e nem havia notoriedade a seu respeito, admite-se o ajuizamento de ação investigatória, ainda que tenha sido aforada uma anterior com sentença julgando improcedente o pedido. Nos termos da orientação da Turma, "sempre recomendável a realização de perícia para investigação genética (HLA e DNA), porque permite ao julgador um juízo de fortíssima probabilidade, senão de certeza" na composição do conflito. Ademais, o progresso da ciência jurídica, em matéria de prova, está na substituição da verdade ficta pela verdade real. A coisa julgada em se tratando de ações de estado, como no caso de investigação de paternidade, deve ser interpretada modus in rebus. Nas palavras de respeitável e avançada doutrina, quando estudiosos hoje se aprofundam no reestudo do instituto, na busca sobretudo da realização do processo justo, "a coisa julgada existe como criação necessária à segurança prática das relações jurídicas e as dificuldades que se opõem à sua ruptura se explicam pela mesmíssima razão. Não se pode olvidar, todavia, que numa sociedade de homens livres, a Justiça tem de estar acima da segurança, porque sem Justiça não há liberdade". Este Tribunal tem buscado, em sua jurisprudência, firmar posições que atendam aos fins sociais do processo e às exigências do bem comum" (REsp. $n^{\circ}$ 226.436/PR, da 4⿳亠丷厂 Turma, Relator o Ministro Sálvio de Figueiredo Teixeira, DJ de 4/2/02).

PROCESSO CIVIL. INVESTIGAÇÃO DE PATERNIDADE. PROPOSITURA DE AÇÃO ANTERIORMENTE AJUIZADA, QUE TEVE SEU PEDIDO JULGADO IMPROCEDENTE PELO NÃO COMPARECIMENTO DA REPRESENTANTE LEGAL DO INVESTIGANDO À AUDIÊNCIA DE INSTRUÇÃO. CONFISSÃO. COISA JULGADA. AFASTAMENTO. DIREITO INDISPONÍVEL. I $\mathrm{Na}$ primitiva ação de investigação de paternidade proposta, a improcedência do pedido decorreu de confissão ficta pelo não 


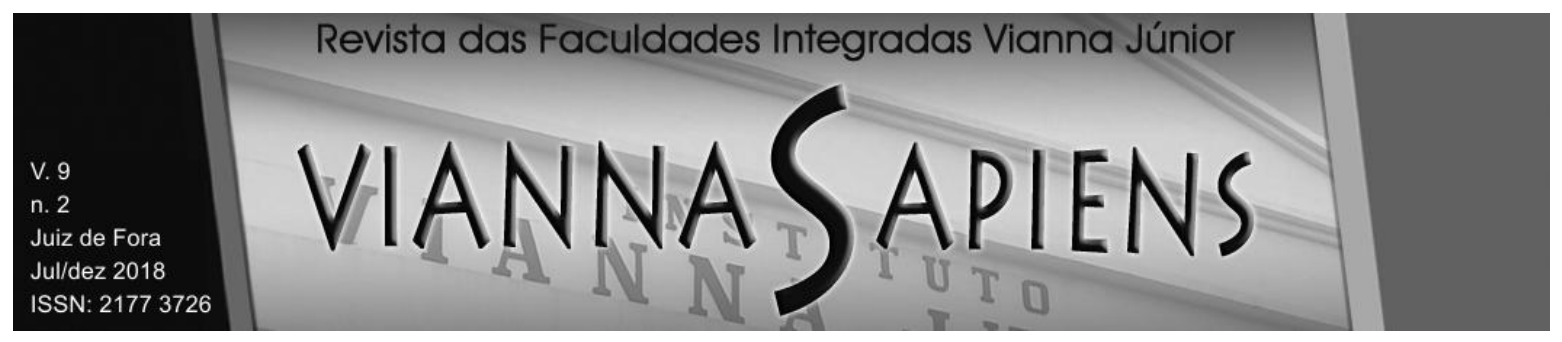

comparecimento da mãe do investigando à audiência de instrução designada. Considerando, assim, que a paternidade do investigado não foi expressamente excluída por real decisão de mérito, precedida por produção de provas, impossível se mostra cristalizar como coisa julgada material a inexistência do estado de filiação, ficando franqueado ao autor, por conseguinte, o ajuizamento de nova ação. É a flexibilização da coisa julgada. II - Em se tratando de direito de família, acertadamente, doutrina e jurisprudência têm entendido que a ciência jurídica deve acompanhar o desenvolvimento social, sob pena de ver-se estagnada em modelos formais que não respondem aos anseios da sociedade. Recurso especial conhecido e provido" (REsp. no 427.117/MS, 3a Turma, rel. Min. Castro Filho, DJ de 16/2/04).

Como visto, o julgamento do RE n`363.889 pelo Pleno do Supremo Tribunal Federal foi importantíssimo para pacificar as doutrinas e jurisprudências a esse respeito, pois até mesmo o Supremo Tribunal padecia de divergências de entendimento entre suas turmas.

\section{O PRINCÍPIO DA DIGNIDADE DA PESSOA HUMANA COMO JUSTIFICATIVA PARA A RELATIVIZAÇÃO DA COISA JULGADA NOS CASOS DE INVESTIGAÇÃO DE PATERNIDADE}

As pedras fundamentais em que se assenta toda a organização política do Estado Democrático de Direito são a dignidade humana e o respeito aos direitos individuais e sociais dos cidadãos, conforme destacado no preâmbulo e no artigo $1^{\circ}$ da nossa Carta Magna. A dignidade da pessoa humana é o vetor do nosso sistema jurídico (GRECO, 2007). Porém, há que se ressaltar que esse princípio não pode ser invocado em qualquer circunstância, sem a devida fundamentação para a sua aplicação, sob pena de restar banalizado. Além disso, doutrinadores como Luís Roberto Barroso elencam uma série de pressupostos que devem estar presentes antes de se invocar tal princípio, aos quais nomeou de "conteúdo mínimo da dignidade humana", são eles: o valor intrínseco da pessoa humana, a autonomia da vontade e valor comunitário (BARROSO, 2010). 


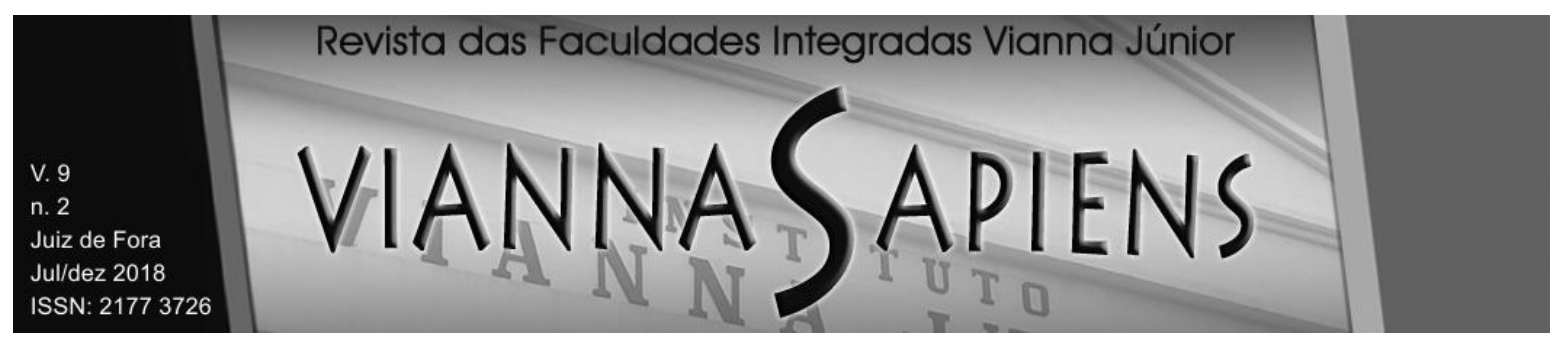

valor intrínseco diz respeito a tudo aquilo que é essencial, intrínseco para o ser humano, é aquele valor que o diferencia dos outros animais. No Recurso Extraordinário objeto de análise, a dignidade se apresenta na forma dos direitos fundamentais, mais especificamente o direito de uma pessoa saber sua origem biológica, atributo de sua personalidade. Fator esse que legitima o embate com 0 princípio da segurança jurídica. A autonomia privada consiste no elemento ético da dignidade, ligando-se à capacidade do homem de autodeterminação, de livremente fazer suas escolhas e tomar os rumos de sua vida, dada sua vontade, sua liberdade e sua responsabilidade. Nesses termos, o elemento da autonomia da vontade se encontra na necessidade de se garantir um mínimo existencial, para que o indivíduo, em sua condição de ser humano livre e igual, seja capaz de exercer sua cidadania, de fazer suas próprias escolhas, sem interferências externas ilegítimas. Incluem-se nesse mínimo existencial o direito à educação básica, à saúde, à assistência aos desamparados e ao acesso à justiça.

No caso em tela, como o próprio Ministro Dias Toffoli asseverou, houve negligência do Estado em fornecer gratuitamente o exame de DNA, uma vez que existem dispositivos legais e constitucionais que garantem o acesso à justiça e assistência judiciária gratuita para os menos abastados.

O valor comunitário, por sua vez, diz respeito ao elemento social da dignidade. É o indivíduo tido como membro da sociedade, compartilhando seus valores, e tendo para com ela deveres e responsabilidades. Sendo assim, podemos perceber que todos os indivíduos tem dignidade, e cada um tem o mesmo valor, não podendo um valor se sobrepor a outro sem critério algum, arbitrariamente. Porém, havendo colisão entre esses valores, um poderá ser afastado, levando-se em conta a ponderação de valores e o método da proporcionalidade.

Não obstante, Luiz Edson Fachin e Carlos Eduardo Pianovski (2008), ao tentarem definir o conteúdo do princípio da dignidade da pessoa humana, bem como seu âmbito de incidência, chegam a conclusão de que tal princípio deve incidir em face à pessoa concretamente considerada e não à pessoa abstrativamente considerada, como mero elemento de uma relação jurídica. E, mais adiante, faz uma 


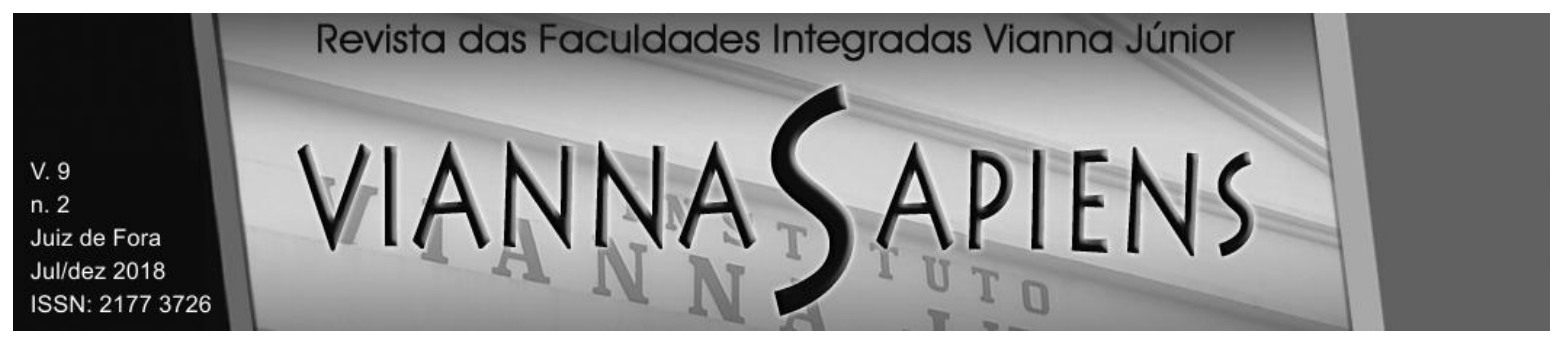

citação dos estudos de Ingo Sarlet citado por Fachin (2008,p. 2) , que define a dignidade como:

\begin{abstract}
Uma qualidade intrínseca e distintiva de cada ser humano que o faz merecedor do mesmo respeito e consideração por parte do Estado e da comunidade, implicando, neste sentido, um complexo de direitos e deveres fundamentais que assegurem a pessoa tanto contra todo e qualquer ato de cunho degradante e desumano, como venham a the garantir as condições existenciais mínimas para uma vida saudável, além de propiciar e promover sua participação ativa e corresponsável nos destinos da própria existência e da vida em comunhão com os demais seres humanos.
\end{abstract}

Sendo assim, embora o eminente Relator do REsp $n^{\circ} 363.889$, não tenha baseado seu voto claramente no princípio da dignidade da pessoa humana, certo é que a análise desse princípio, ainda que como plano de fundo, é fundamental para a ponderação de interesses, principalmente se levarmos em consideração que os direitos da personalidade, invocados pelo advogado do autor da demanda, são decorrentes da dignidade da pessoa humana, espinha dorsal da nossa Constituição Federal.

Nessa toada, o jurista italiano Stefano Rodotà defende que, havendo colisão entre princípios o melhor caminho é reconhecer nos chamados direitos da personalidade expressões da irrestrita proteção jurídica à pessoa humana e, portanto, atribuir-lhes a natureza de princípios de inspiração constitucional. Assim, esses litígios deverão ser examinados através do já amplamente aceito mecanismo da ponderação, com o objetivo de verificar, no caso concreto, onde se realiza mais plenamente a dignidade da pessoa humana, conforme determinação constitucional (MORAES, 2010).

É exatamente a situação encontrada no REsp $n^{\circ} 363.889$, onde existe uma clara colisão de princípios constitucionais.

Para o jurista supracitado, o nome a e imagem da pessoa são aspectos fundamentais da personalidade, que receberam destaque na tutela do Código Civil e cuja importância decorre não apenas do fato de atuarem como os sinais 


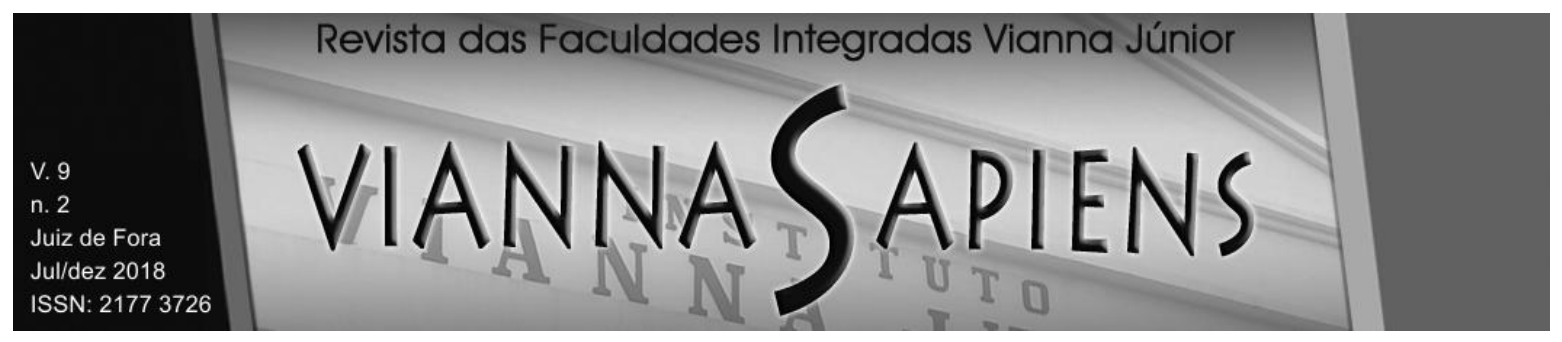

designativos que indicam a individualização da pessoa no meio social, mas também por constituírem manifestações intrínsecas da individualidade pessoal, dizendo respeito, portanto, ao seu interesse mais essencial (MORAES, 2010).

Partindo desses pressupostos, o Supremo Tribunal Federal, por maioria, decidiu que a verdade biológica do autor, após uma correta ponderação de interesses, deve prevalecer sobre a imutabilidade da coisa julgada material, por ser ela atributo da personalidade e estar mais próxima do princípio da dignidade da pessoa humana. Nesse sentido, qualquer elemento de identificação, quer pessoal, quer resultante da vida em relação, que seja peculiar ou torne peculiar uma pessoa, assim como seu nome, integrará sua identidade, enquanto compreendida como expressão objetiva da dignidade humana. A identidade genética, a origem genética de cada indivíduo, indica mais um dos elementos de individualização da personalidade (BARBOZA, 2002). Nesse sentido, Helsa Helena Barboza( 2002, p. 389) asseverou:

entre nós, tem-se reconhecido a distinção entre a identidade genética ou origem genética e o estado de filiação, como um direito da personalidade, na medida em que constitui uma das mais legítimas e concretas expressões da personalidade humana, sendo talvez a última fronteira em termos de individualização, já que por ora, imutável.

Sendo assim, o direito fundamental ao conhecimento de sua origem genética, nos casos específicos em que não houve a produção de prova pericial de DNA, deve prevalecer em relação a coisa julgada material, em homenagem ao princípio da dignidade da pessoa humana e da verdade real.

Em relação a essa polêmica, a decisão do Supremo Tribunal Federal no REsp $n^{\circ} 363.889$ pacificou o entendimento que era divergente nos tribunais e na doutrina. Porém, não podemos nos esquecer da possibilidade de ocorrer situações, nas quais o réu foi considerado pai, sem haver, contudo, a realização do exame de DNA. Será que se pode falar em desconsideração da coisa julgada para extinguir a condição de filho, sendo proposta nova demanda por aquele que foi juridicamente considerado 


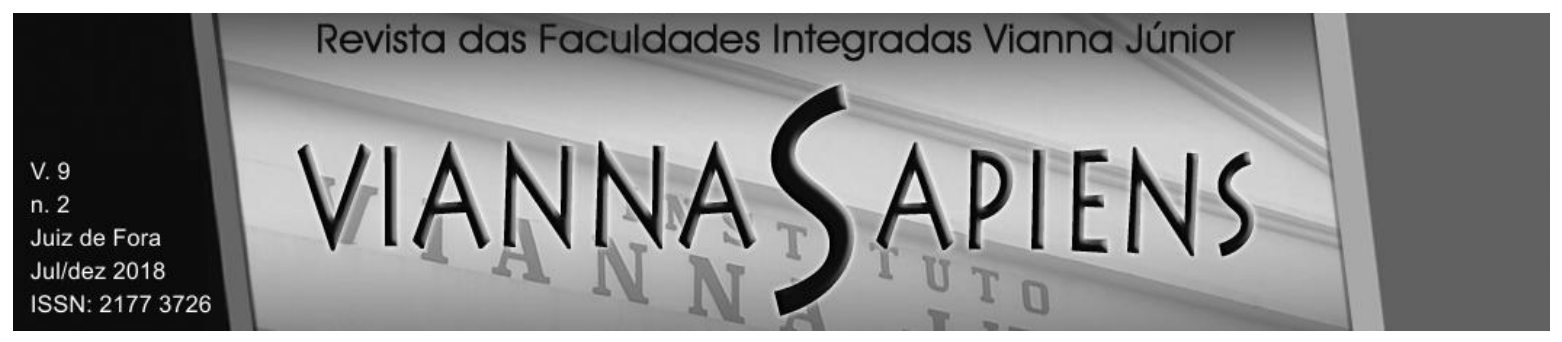

pai? Pietro Perlingieri ( 2007) defende que a imprescritibilidade das ações de estado deve se dar apenas em relação ao filho, que é aquele indivíduo que sofrerá alteração no seu status. Vale dizer que as ações tendentes a negar ou modificar o status de outrem, somente estarão aptas a quebrar a coisa julgada e consequentemente a segurança jurídica quando estiverem vinculadas a ações positivas. Segundo o autor:

As ações de estado, que tendem em via principal a reclamar, contestar ou modificar os status pessoais, de regra, são imprescritíveis quando a pessoa age para afirmar seu próprio status [...] e são prescritíveis quando o legitimado age para contestar ou modificar status de outrem (PERLINGIERI 2007, p.134).

Essa posição é defendida pela professora Rose Melo Vencelau ( 2011, p. 710), para quem "a garantia da segurança jurídica se dirige ao filho, porque o status de filiação estabelecido integra a sua identidade" .

Sendo assim, por hora, a relativização da coisa julgada material só pode ocorrer em benefício daquele que busca o status pessoal de filho, nos casos em que não houve a realização da prova pericial de DNA, em benefício de seus direitos personalíssimos.

\section{CONCLUSÕES}

Finalmente, podemos concluir na análise do $R E n^{\circ} 363.889 / D F$, que a maioria dos Ministros do Supremo Tribunal Federal, ao se valerem do princípio da dignidade da pessoa humana como instrumento para a ponderação dos valores postos em conflito, decidiram por afastar a coisa julgada, para permitir que a demanda seja novamente apreciada, com fins de se realizar o exame de DNA, garantindo ao autor o conhecimento de sua identidade biológica. Como já noticiado, diante de uma situação delicada como o direito fundamental à filiação, não pode o Estado-juiz negar a busca pela verdade biológica do indivíduo, em razão da estabilidade 


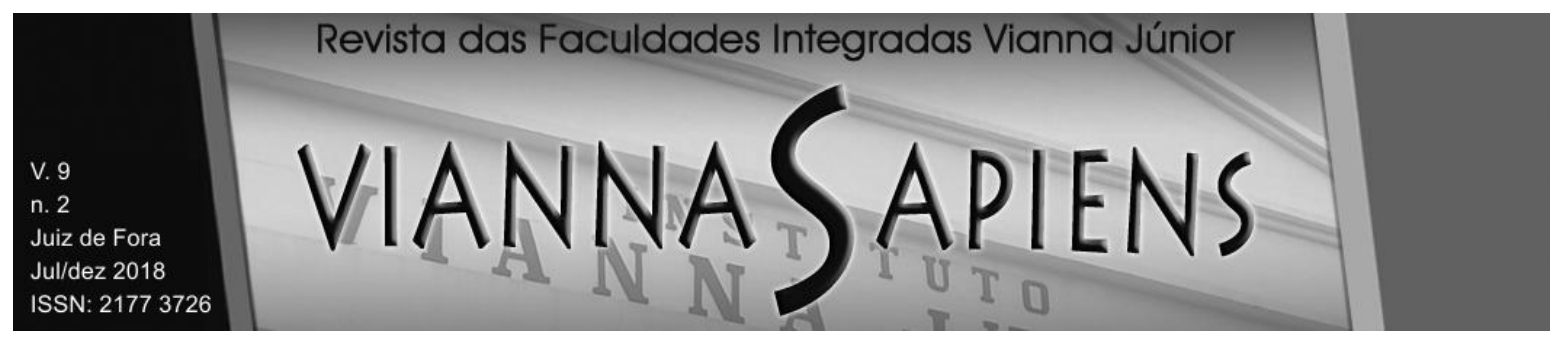

promovida pela coisa julgada material. Isto ocorre devido ao fato de que as informações sobre a paternidade integram os direitos da personalidade, corolários do princípio da dignidade da pessoa humana. Decisão diversa da que foi tomada pela Excelsa Corte, significaria retirar a responsabilidade parental do pai biológico, consolidando assim a não filiação.

Trata-se, na verdade, do direito ao conhecimento da identidade genética do cidadão, cujo bem jurídico tutelado é a descoberta de sua origem biológica, que se considera como atributo intrínseco à personalidade humana, direito essencial ao nome de família, que aponta a sua ascendência genética, o seu status de filiação, ficando a análise dos direitos patrimoniais em segundo plano.

Além disso, é inegável reconhecer que houve um avanço significativo em relação aos meios de prova, mais especificamente em relação ao exame de DNA, que atualmente é considerado um meio de prova imprescindível para orientar a decisão judicial.

Somando-se a esta situação, o $\operatorname{RE~} n^{\circ} 363.889$, trouxe a tona também a omissão estatal em custear o exame de DNA, sendo que a parte se encontrava sob assistência judiciária gratuita, não tendo condições de arcar com os custos elevados dessa prova pericial e que, atualmente, o Estado, por entender que direito a conhecer a origem genética é atributo da personalidade, custeia esse exame para aqueles que se encontram em gozo da assistência judiciária gratuita. Frise-se que a desconsideração da coisa julgada é muito séria e traz grandes impactos ao ordenamento jurídico, visto que afasta a incidência de princípios importantíssimos como o da segurança jurídica e do Estado de Direito.

Por esta razão, qualquer forma de afastamento da definitividade da coisa julgada material deve ser fundamentada na prevalência de outros princípios constitucionais que, através de uma correta ponderação, se revelem mais condizentes com o valor-base de nosso ordenamento jurídico, qual seja a dignidade da pessoa humana. 


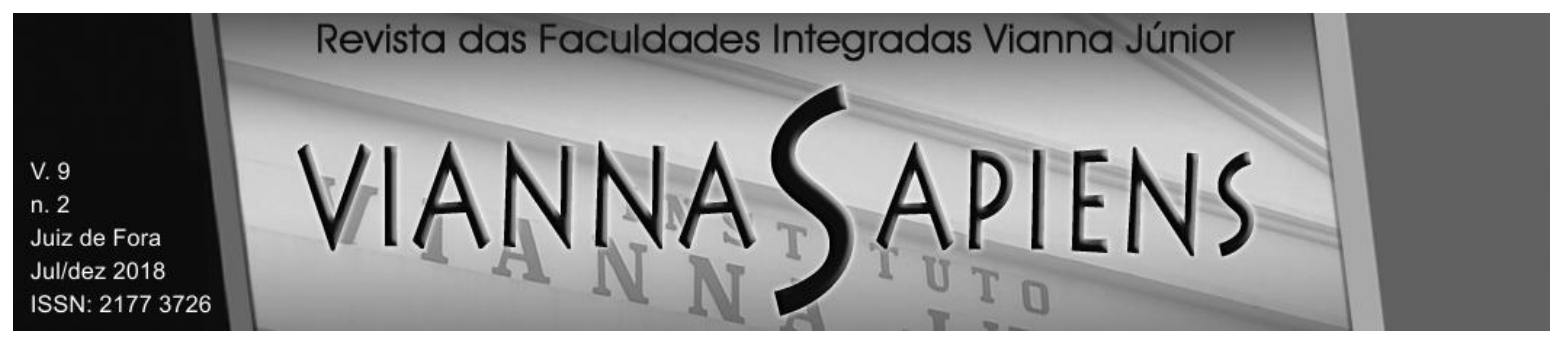

\section{REFERÊNCIAS}

BARBOZA, Heloísa Helena. Direito à identidade genética. In Anais do III Congresso Brasileiro de Direito de Família. Coord. Rodrigo da Cunha Pereira. Belo Horizonte: IBDFAM/Del Rey, 2002.

\section{BARROSO, Luís Roberto. A Dignidade da pessoa humana no Direito}

Constitucional Contemporâneo: natureza jurídica, conteúdos mínimos e critérios de aplicação. Disponível em: <http://www.osconstitucionalistas.com.br/wpcontent/uploads/2010/12/LRBarroso-A-dignidade-da-pessoa-humana-no-Direito Constitucional-contemporaneo.pdf>. Acesso em 30 abr. 2018.

BRASIL. Constituição Federal da República Federativa do Brasil. Vade Mecum. 6. ed. atual. e ampl. São Paulo: Saraiva, 2008.

BRASIL. Código Civil. Vade Mecum. 6. ed. atual. e ampl. São Paulo: Saraiva, 2008.

BRASIL. Estatuto da Criança e do Adolescente. Vade Mecum. 6. Ed. atual. e ampl. São Paulo: Saraiva, 2008.

BODIN DE MORAES. Maria Celina. Na medida da pessoa humana: estudos de direito civil. Rio de Janeiro: Renovar, 2010.

CÂMARA, Alexandre Freitas. Lições de Direito Processual Civil. V.1. 9. ed. Rio de Janeiro: Lumen Juris, 2003.

CINTRA, Antônio Carlos de Araújo; GRINOVER, Ada Pellegrini; DINAMARCO, Cândido Rangel. Teoria Geral do Processo. 14 ed. São Paulo: Malheiros, 1998.

FACHIN, Luiz Edson; PIANOVSKI, Carlos Eduardo. A dignidade da pessoa humana no direito contemporâneo: uma contribuição à crítica da raiz dogmática do neopositivismo constitucionalista. Revista Trimestral de Direito Civil. Vol. 35. Pág. 1 a 24. Jul/Set. Rio de Janeiro: Padma, 2008. 


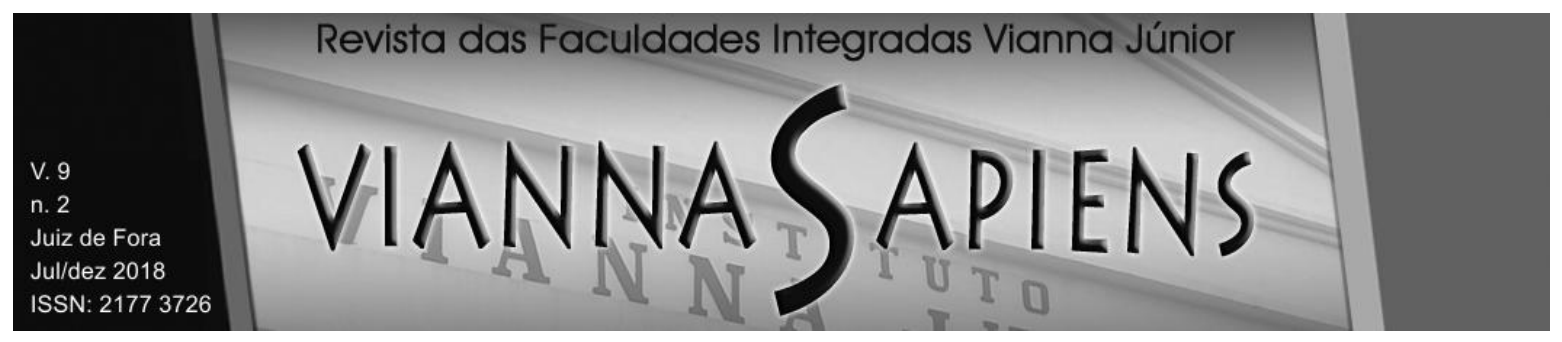

GRECO, Leonardo. Eficácia da declaração erga omnes de constitucionalidade ou inconstitucionalidade em relação à coisa julgada anterior. Disponível na Internet: <http://www.mundojuridico.adv.br>. Acesso em 30 abr. 2018.

GRECO, Leonardo. Garantias Fundamentais do processo: o processo justo. Disponível na Internet: <http://www.mundojuridico.adv.br>. Acesso em 30 abr. 2018.

LÔBO, Paulo Luiz Netto. Direito ao estado de filiação e direito à origem genética: uma distinção necessária. In: Revista Brasileira de Direito de Família, $n^{\circ} 19$, agoset/2003.

MARINONI, Luiz Guilherme. Sobre a chamada "relativização" da coisa julgada material. Disponível em: <http://www.pdf4free.com>. Acesso em: 30 abr. 2018.

PERLINGIERI, Pietro. Perfis do Direito Civil: introdução ao Direito Civil Constitucional. 3 ed. Rio de Janeiro: Renovar, 2007.

SUPREMO TRIBUNAL FEDERAL. RE $\mathbf{n}^{\circ}$ 363.889. Pleno. Rel. Min. Dias Toffoli. Publicado no DJ em 16/12/2011. Disponível em: <http://www.stf.jus.br>. Acesso em 30 abr. 2018.

SUPERIOR TRIBUNAL DE JUSTIÇA. REsp. no 226.436. 4를 Turma, Relator Min. Sálvio de Figueiredo Teixeira. Julgado em 04/02/02. Disponível em: <http://www.stj.jus.br>. Acesso em 30 abr. 2018.

SUPERIOR TRIBUNAL DE JUSTIÇA. REsp. no 427.117. 3를 Turma, Relator Min. Castro Filho. Publicado no DJ em 16/02/04. Disponível em: <http://www.stj.jus.br>. Acesso em 30 abr. 2018.

SUPERIOR TRIBUNAL DE JUSTIÇA. REsp. $\mathbf{n}^{\circ}$ 653.942. 4. ํㅜ Turma, Relator Min. Honildo Amaral de Mello Castro. Julgado em 15/09/09 Disponível em:

<http://www.stj.jus.br>. Acesso em 30 abr. 2018. 


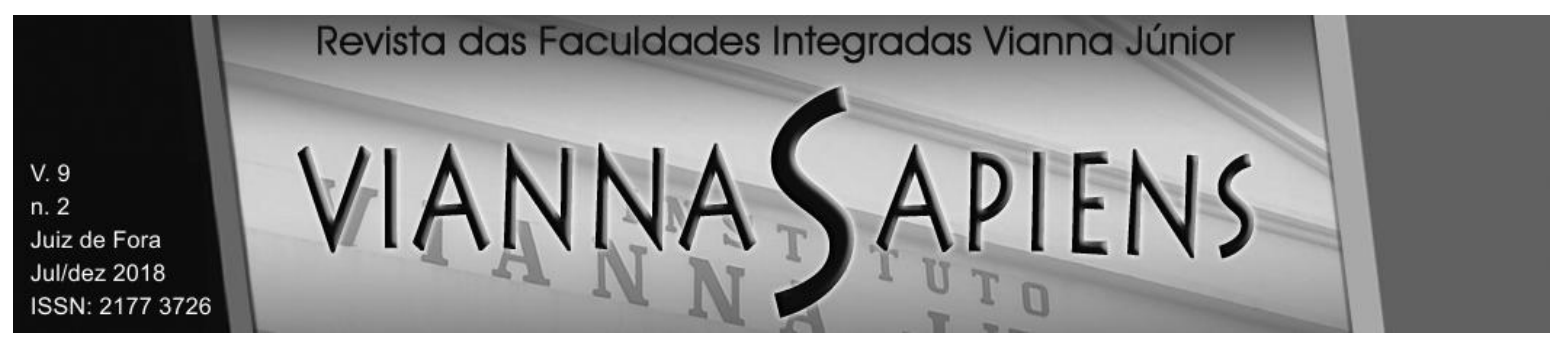

SUPERIOR TRIBUNAL DE JUSTIÇA. REsp. no 300.084. 2. a Seção, Relator Min. Humberto Gomes de Barros. Julgado em 28/04/04. Disponível em:

<http://www.stj.jus.br>. Acesso em 30 abr. 2018.

TEPEDINO, Gustavo; FRAZÃO, Ana. O Superior Tribunal de Justiça e a reconstrução do direito privado. São Paulo: Revista dos Tribunais, 2011.

THEODORO JUNIOR., Humberto. Curso de Direito Processual Civil. Vol. I. 48 ed. Rio de Janeiro: Forense, 2008.

Recebido em 30/04/2018

Publicado em 21/12/2018 